\title{
The use of Flash Laser Method in the analysis of thermal diffusivity of metallic materials
}

\author{
BOLSANELLO, M. B. ${ }^{1}$ MACHADO, C. S. C. ${ }^{1}$; ORLANDO, M. T. D. ${ }^{2}$, ROSSI, J. L. ${ }^{1,}$ \\ mfbolsanello@ipen.com \\ ${ }^{1}$ Instituto de Pesquisas Energéticas e Nucleares, IPEN - CNEN/SP \\ Av. Lineu Prestes, 2242 - Cidade Universitária - 05508-00 - São Paulo - Brasil \\ ${ }^{2}$ Universidade Federal do Espírito Santo
}

Av. Fernando Ferrari, 514 - Goiabeiras - Vitória - Espírito Santo - 29075-910 - Brasil

* e-mail: mfbolsanello@ipen.br

\section{Resumo}

A eficácia do método de análise de difusividade térmica de materiais metálicos denominada Flash Laser foi analisada e comprovada a partir de estudos com um aço inoxidável duplex. Este método é baseado na solução analítica da equação de difusão térmica unidimensional, e sua importância se deve ao fato de que as propriedades termofísicas de um material são a chave para determinar sua aplicação e performance perante as condições térmicas a ele impostas. O método Flash Laser consiste na utilização de uma amostra cilíndrica, submetida a condições adiabáticas, a qual recebe um pulso de laser inicial em uma das faces. Na face oposta é medida a variação no perfil de temperatura e obtida uma curva de temperatura experimentalmente. A partir daí, é possível determinar pela espessura da amostra e o tempo necessário para que o aumento de temperatura na face posterior da amostra atinja a metade do seu valor máximo, os dados obtidos são aplicados a uma fórmula sugerida por Parker para a determinação da difusividade térmica do material estudado. Foi analisada uma amostra de aço inoxidável duplex UNS S32304 tal como recebida pelo fabricante, e o valor obtido pelo método em questão foi comparado com aquele fornecido nas especificações técnicas do material, o que garantiu a eficácia do método. Uma vez comprovada sua eficiência, o método Flash Laser será usado para analisar possíveis alterações na difusividade térmica do mesmo metal devido à soldagem.

\section{Abstract}

The method effectiveness for thermal analysis of metallic materials named Flash Laser was analyzed and proved from studies concerning duplex stainless steel. This method is based on the analytical solution of the unidimensional thermal diffusivity equation, and its importance comes from the fact that material thermophysical properties are the key to determine its application and performance in the face of thermal conditions imposed. Flash Laser method consists in the use of a cylindrical sample, in adiabatic conditions, which receives an initial pulse of laser in one of the faces. On the opposite side, the range of temperature profile is measured, and an experimental curve is obtained. From then on, it's possible to determine time required to increase the temperature of the opposite side to the half of its maximum. With this information in hands, and knowing the thickness of the sample, these data are applied to Parker equations to determine the thermal diffusivity of the studied material. A sample of stainless steel UNS S32304 was analyzed in the condition as received from the supplier, and the value obtained with the method in focus was compared to the one exposed on the material technical specifications. This baseline ensured the effectiveness of the Flash Laser method. Once qualified, Flash Laser method will be employed in the analysis of possible modifications on the thermal diffusivity of metals due to welding process.

\section{Introduction}


closely related to the knowledge of materials thermophysical properties. In many cases, equipment failures, design errors and performance noncompliance are consequences of misinformation involving materials key-properties, which should be considered in the systems initial analysis.

Data selection, as well as the knowledge of the material properties are a decisive part on engineering projects. This reinforces the importance of the development of a reliable procedure to determine materials thermal diffusivity, and to analyze the conditions which the material will be submitted that can affect this property.

Thermal diffusivity is defined, to a

$$
\alpha=\frac{k}{Q}=\frac{k}{\rho \cdot c_{p}} .
$$

certain material, as the reason between its capacity to conduct heat, and its capacity to store heat.

Thermal diffusivity

$$
=\frac{\text { Capacity to conduct heat }}{\text { Capacity to store heat }} \text {. }
$$

Which means:

The list of materials properties that influences on heat transference is extensive, and they're named thermophysic properties. They are subdivided in transport properties and thermodynamic properties. The first group concerns the diffusion coefficient, such as thermal conductivity (k), applied on heat transference, and cinematic viscosity (v), for momentum transference. On the other hand, thermodynamic properties refer to systems steady state, such as density $(\rho)$, and specific heat $\left(c_{p}\right)$. Its product, $\rho c_{p}\left(\mathrm{~J} /\left(\mathrm{m}^{3} / \mathrm{K}\right)\right)$, known as volumetric heat capacity $(Q)$, measures a material capacity to storage thermal energy.

So, in heat transference analysis, the ratio between the thermal conductivity and the heat capacity can be rewritten as:

Materials with high values of $\alpha$ will respond more rapidly to changes on thermal conditions imposed, while materials with low values of $\alpha$ will respond slowly, which means that they will take more time to reach equilibrium.

\subsection{Flash Laser Method to determination of thermal diffusivity}


Consider a disk as being a flat and infinite plate, very thin, with a unidimensional heat flux, perpendicular to samples parallel sides. Temperature analysis on samples sides is as a function of space and time, $(x, t)$; after being exposed to a laser pulse, it is possible to notice a temperature difference between the sides. For a temperature gradient between samples sides and considering a unidimensional system, due adiabatic conditions, it's possible to apply Fourier series to solve the problem:

Manipulating the equation, and making the considerations needed, we arrive to:

$$
T(x, t)=\frac{1}{L} \int_{0}^{L} T(x, 0) d x+\frac{2}{L} \sum_{n=1}^{\infty} \exp \left(\frac{-n^{2} \pi^{2} a t}{L^{2}}\right) \cos \frac{n \pi x}{L} \int_{0}^{L} T(x, 0) \cos \frac{n \pi x}{L} d x .
$$

Where $\alpha$ is the thermal diffusivity.

$$
\begin{aligned}
T(x, t)=\frac{a_{0}}{2}+ & \sum_{n=1}^{\infty}\left[a_{n} \cos \frac{n \pi x}{L}\right. \\
& \left.+b_{n} \sin \frac{n \pi x}{L}\right] .
\end{aligned}
$$

If a pulse under the form of a beam of radiant energy $Q \quad[\mathrm{~J} / \mathrm{m} 2]$ is instantly and evenly absorbed in a small depth $\mathrm{g}$ of front surface $\mathrm{x}=0$ of a solid with thickness $L[\mathrm{~m}]$ thermally insulated, temperature distribution at the dime is given by $T(x, 0)=$ $\mathrm{Q} /\left(\rho c_{p} g\right)$ for $0 .<. \mathrm{X} .<. \mathrm{g}$ and $\mathrm{T}(\mathrm{x}, 0)=$ 0 for $\mathrm{g}<\mathrm{x}<\mathrm{L}$. From this initial condition, equation is developed to:

$$
T(x, t)=\frac{Q}{\rho c_{p} L}\left[1+2 \sum_{n=1}^{\infty} \exp \left(\frac{-n^{2} \pi^{2} \alpha t}{L^{2}}\right) \cos \frac{n \pi x}{L} \frac{\sin \frac{n \pi g}{L}}{\frac{n \pi g}{L}}\right] .
$$

Once $g$ is small for opaque materials, it's possible to consider that $\quad \sin \frac{n \pi g}{L} \approx \frac{n \pi g}{L}$. So, the temperature in any point-in-time on the opposite side $(x=L)$ is given by: 


$$
\begin{aligned}
& T(x, t) \\
& =\frac{Q}{\rho c_{p} L}[1 \\
& \left.+2 \sum_{n=1}^{\infty}(-1)^{n} \exp \left(\alpha \frac{-n^{2} \pi^{2}}{L^{2}} t\right)\right] .
\end{aligned}
$$

Thus, it's possible to determine two dimensionless parameters:

$$
\begin{array}{r}
V(L, t)=\frac{T(L, t)-T_{0}}{T_{M}-T_{0}} \\
=\frac{\Delta T(L, t)}{\Delta T_{m}}, \\
\omega=\frac{\pi^{2} \alpha t}{L^{2}} .
\end{array}
$$

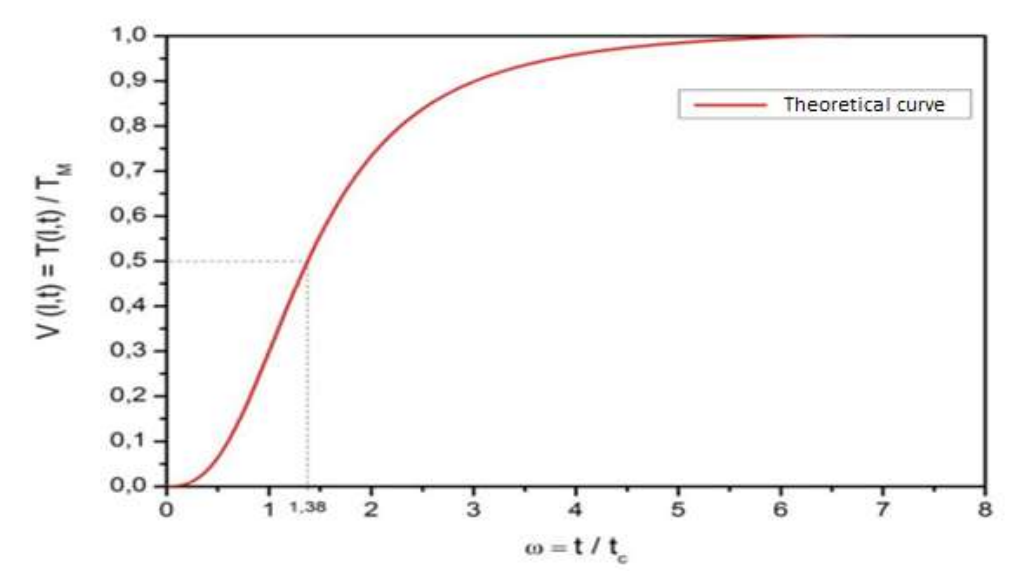

Notice that $\mathrm{V}(\mathrm{L}, \mathrm{t})$ is the dimensionless increase of temperature in the opposite side of the sample. So, it's possible to rewrite the equation 6 as:

According to the equation above, Parker et al. (1961) plotted the following chart:

Figure 1 - Measures of thermal diffusivity by Flash Laser Method.

$$
\begin{aligned}
& V(L, t) \\
& =1+2 \sum_{n=1}^{\infty}(-1)^{n} \exp \left(-n^{2} \omega\right) .
\end{aligned}
$$

Parker suggested that, based on the equation 9, when $\mathrm{V}$ assumes the value of $0,5, \omega$ is equal to 1,38 . So, replacing those values on the equation 8 , is obtained that:

$$
\alpha_{0}=1,38 \frac{L^{2}}{\pi^{2} t_{1 / 2}} .
$$

where $t_{1 / 2}$ is the time required for the temperature increase on the 
as pulse finite time effects and thermal exchanges. So, it's necessary to apply procedures that take into account those effects, to make corrections on the obtained results. A correction factor $\tau$ is then used, and the correct thermal diffusivity value is given by:

$$
\alpha=\tau . \alpha_{0} .
$$

\section{Materials and methodology}

Table 1 - Stainless steel UNS S32304 data given by the supplier.

\begin{tabular}{ll}
\hline Density & $7,8 \mathrm{~g} / \mathrm{cm}^{3}$ \\
\hline Modulus of elasticity & $200 \mathrm{GPa}$ \\
\hline Average coeficiente of termal expansion & \\
from $0{ }^{\circ} \mathrm{C}$ to $100{ }^{\circ} \mathrm{C}$ & $13,0 \mu \mathrm{m} / \mathrm{m} \cdot{ }^{\circ} \mathrm{C}$ \\
from $0{ }^{\circ} \mathrm{C}$ to $538^{\circ} \mathrm{C}$ & $14,0 \mu \mathrm{m} / \mathrm{m} \cdot{ }^{\circ} \mathrm{C}$ \\
\hline Thermal conductivity at $100{ }^{\circ} \mathrm{C}$ & $17 \mathrm{~W} / \mathrm{m} \cdot \mathrm{K}$ \\
\hline Specific heat & $450 \mathrm{~J} / \mathrm{Kg} \cdot \mathrm{K}$ \\
\hline Electrical resistivity & $0,8 \mu \Omega \mathrm{m}$ \\
\hline Melting point & $1465{ }^{\circ} \mathrm{C}$ \\
\hline
\end{tabular}

2.2 Thermal diffusivity

\section{measurement}

Thermal diffusivity measurements were done at PRESSLAB/UFES, with fixed and known temperatures. Specifications of the equipment used on experimental table for the

\subsection{Material}

The analyzed material was the UNS S32304, a low alloy stainless steel. The point token for study was exactly in the middle of the sample, to avoid border effects and residual stresses or heating resulting of the cutting process.

The Table 1 below shows the materials data, given by the supplier. 
Offers a wavelength of $10^{-6}$ $\mathrm{m}$, intensity of $10 \sqrt{2} \mathrm{~W} / \mathrm{m}^{2}$ and $2 \mathrm{~mm}$ diameter.

- Thermocouple responsible for the temperature analysis, type $\mathrm{J}$, for a range between 0 ${ }^{\circ} \mathrm{C}$ and $480{ }^{\circ} \mathrm{C}$.

- Amplifier board responsible for the amplification of the signal arising from the thermocouple and its transmission to the computer. Type BD T422. Amplification relation of $1 / 1000$. The sign is so converted by a converser type PCl 711 AD 8 bits that works in a voltage variation of $\pm 5 \mathrm{~V}$.

- IBM computer, used for data acquisition and chat plot (potential difference vs. time). The used program was DIFU $3 \mathrm{~A}$, developed by high pressure laboratory from Federal University of Espírito Santo (PRESLAB/UFES).

The bench scheme is shown on Figure 2 below:

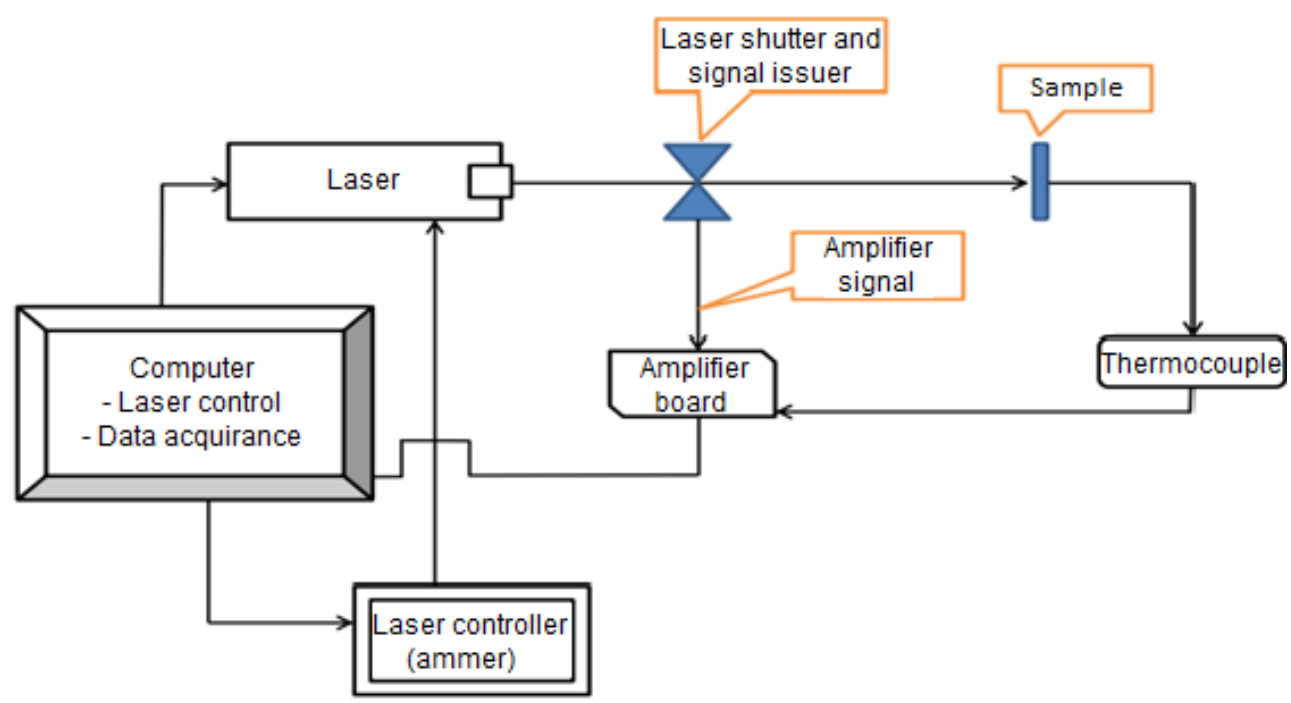

Figure 2 - Scheme of the bench used to determine materials thermophysical properties by Flash Laser method at PRESLAB - UFES.

\section{Results}

\subsection{Results from the supplier data}

Based on data shown at the Table 1 , and considering that the thermal diffusivity of a material is the ratio between its capacity to conduct heat and its capacity to storage it, it's obtained that:

$$
\alpha=\frac{k}{\rho \cdot c_{p}} .
$$


Where:

$\alpha$ is thermal diffusivity;

$k$ is thermal conductivity;

$\rho$ is the materials specific mass;

$c_{p}$ is the specific heat.

Replacing the literature values to the analyzed steel:

$$
\alpha=4,364 \cdot 10^{-6} \frac{\mathrm{m}}{\mathrm{s}^{2}}
$$

\subsection{Results from Flash Laser method}

The graphic below presents the temperature of the opposite side versus the experimental time. By its analysis, it's possible to obtain initial and final times of the pulse application, as well as temperature fluctuation, enabling the determination of the time in which the temperature on the opposite side achieves half of the maximum value, in other words, $t_{1 / 2}$.

Knowing the thickness of the sample, it's possible to obtain the thermal diffusivity value based on the following calculation.

It is worth pointing that, for finite pulse effect corrections, it was used $\tau=0,5$. Besides that, it was adopted that $\pi=3,14159$.

The temperature graphic on the opposite side of the sample as a function of time is shown below:

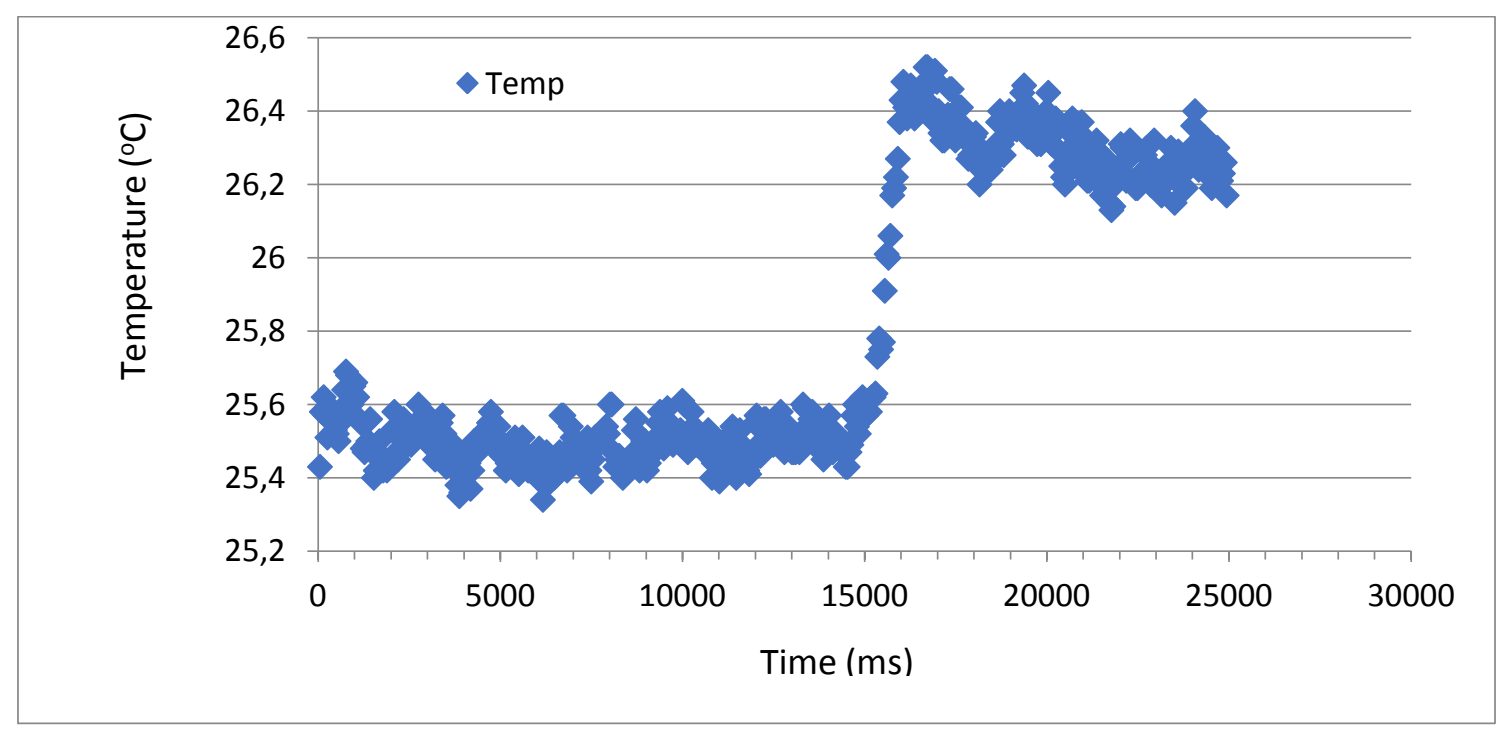

Figure 3 - Graphic of temperature at the opposite side of the sample in function of the experimental time. 
$t_{\text {initial }}=15,147 \mathrm{~s}$. It's also known that the sample thickness $L$ is 0,001807 m. So:

$$
\begin{aligned}
& \Delta t=t_{\text {final }}-t_{\text {initial }}=0,867 s \rightarrow t_{1 / 2} \\
& =0,4795 \mathrm{~s} \\
& \propto_{0}=\frac{1,38 \cdot L^{2}}{\pi^{2} \cdot t_{1} / 2}=\frac{1,38 \cdot 0,001807^{2}}{\pi^{2} \cdot 0,4795} \\
& =9,522 \cdot 10^{-7} \mathrm{~m} / \mathrm{s}^{2}
\end{aligned}
$$

Correcting the finite pulse error, thermal diffusivity will be:

$$
\begin{gathered}
\propto=\propto_{0} \cdot \frac{\tau}{t_{1 / 2}}=9,522 \cdot 10^{-7} \cdot \frac{0,5}{0,4795} \\
=4,2 \cdot 10^{-6} \frac{\mathrm{m}}{\mathrm{s}^{2}} \\
\text { Error }=2,1 \cdot 10^{-7}
\end{gathered}
$$

\section{Discussion}

Comparing the results obtained by flash laser method to the one based on the supplier given data, and reinforcing that both values were obtained for the same material UNS S32304 stainless steel on manufacturing conditions - it is possible to notice that the values found are correspondent.

Considering the error inherent to the flash laser method, it is possible to state that the value of thermal diffusivity is between $\propto$ +error and $\propto$-error. In another words, the true value of $\propto$ is between $3,99 \cdot 10^{-6} \frac{\mathrm{m}}{\mathrm{s}^{2}}$ and $4,41 \cdot 10^{-6} \frac{\mathrm{m}}{\mathrm{s}^{2}}$. Once the thermal diffusivity found by calculation was $\alpha=4,364.10^{-6} \frac{m}{s^{2}}$, contained in this range, it is possible to say that the values obtained by both methods were the same.

\section{Conclusion}

The equivalency between the value of thermal diffusivity resulted from calculation using the data from the supplier and the one obtained by Flash Laser method proves the efficiency of this method for the analyzed material. As subsequent steps, it is intended to use the Flash Laser method to investigate other materials and the influence of thermomechanical processes on materials thermal diffusivity.

\section{References}

VAROL, I; BAESLACK, W; AND LIPPOLD, J. Characterization of Weld Solidification Cracking in a Duplex Stainless Steel. Materials Characterization, 1997, 39, 555573.

CASTELETTI, L.C; AND MARTINS, $M$. Effect of heat treatment on the mechanical properties of ASTM A 890 Gr6A super duplex stainless steel. Journal of ASTM International 2005, 2, 1-14. 
PARKER, W.J; JENKINS, R.J; BUTLER, C.P; AND ABBOTT, G.L. Flash Method of Determining Thermal Diffusivity, Heat Capacity, and Thermal Conductivity. Journal of Applied Physics, 1961, 32, 1679.

KNYAZEVA, M; AND POHL, M. Duplex Steels. Part II: Carbides and Nitrides.
Metallography,
Microstructure, and Analysis 2013, 2, 343-351.

VIJAYALAKSHMI, $\quad \mathrm{K}$; MUTHUPANDI, $\quad \mathrm{V} ; \quad$ AND JAYACHITRA, R. Influence of heat treatment on the microstructure, ultrasonic attenuation and hardness of SAF 2205 duplex stainless steel. Materials Science and Engineering, 2011, A 529, 447-451. 